\title{
BAP1-Mutant Clear Cell Renal Cell
}

\section{Carcinoma}

National Cancer Institute

\section{Source}

National Cancer Institute. BAP1-Mutant Clear Cell Renal Cell Carcinoma. NCI Thesaurus.

Code C157614.

A clear cell renal cell carcinoma that is associated with a mutation in BAP1 gene. These tumors are typically high grade and associated with poor outcome. 